DE DE GRUYTER OPEN
J oumal of Interc ultural Management

Vol. 5, No. 1, March 2013, pp. 63-70

DOI 10.2478/jo im-2013-0005

Fabiola Ponce Durán ${ }^{1}$

\title{
Reflections of interc ultural communication from the perspective of a foreign teacher
}

\begin{abstract}
The challenges of the globalized world, the constant progress of science and technology increasingly lead to a state of interdependence between countries which should lead to intercultural relations generate an attitude of respect for diversity with a more humane vision of life to work in international teams. Universities as organizations embedded in the dynamics of globalization offer academic programs with international or multicultural approach that encourage the development of skills, aptitudes and values according to international defendant. To do this, the recruitment of foreign personnel becomes imperative in meeting planned objectives, so the challenge of foreign teachers is presented to be inserted in different cultural environments transcend and reach their educational work in the formation of their students.

The aim of this paper is to offer some reflections on the importance of intercultural communication product born of the increasing mobility of teachers who face the challenge of surviving in a country with different culture.
\end{abstract}

Keywords: Intercultural communication, culture.

\section{Introduction}

Culture is an inseparable factor of the processes of economic, social and political development of mankind [Vargas, 2007], multiculturalism is to describe the interaction between two or more cultures in a horizontal and synergistic so that none overlaps other and thus promotes the integration and harmonious coexistence among individuals and organizations.

1 Estudiante Doctorado en Ciencias Administrativas, adscrito al Programa Nacional de Posgrado de Conacyt. Universidad de Occidente, Tel. 0052667754 61 47, correo electrónico: fabiolaponceduran@gmail.com 


\section{Fabiola Ponce Durán}

The opening of borders as a result of the phenomenon of globalization and technological development has led to labor mobility, being common to see people from other countries with different cultures interact in the same field of work.

Universities to fulfill their mission of educating highly trained and with an international vision offering academic programs with a multicultural approach that encourage the development of skills that transform students as global citizens, able to live in different cultural settings and within development of scientific and technological increasingly aggressive, skilled in handling languages and able to function in an environment of constant change.

To meet the academic requirements of their programs the universities hire foreign staff to work on campuses and thus contribute to the formation of competitive people with an international vision.

To this comes the question What is the role of intercultural communication in the immersion of these personnel to a foreign culture?

It aims to highlight the importance of intercultural communication from the personal reflections of a foreign teacher in front of a different culture.

\section{Objective}

To offer some reflections on the importance of intercultural communication product born of the increasing mobility of teachers who face the challenge of surviving in a country with different culture and identify critical factors.

\section{Theoretical and conceptual framework}

The word culture has many meanings from different disciplines and within each with different theoretical approach. Thus, we emphasize that in the psychological perspective that regards culture that allows the individual to integrate a given society is expressed through behaviors and attitudes typical [Ralph Linton, 1969], "the configuration of learned behavior and results of behavior whose elements share and transmit the members of a society."

For Terry and Franklin [1985], the term culture refers to learned behavior or life patterns prevailing in a broad sense, or a system of values and sanctions of society in a strict sense.

Early studies of culture from the anthropological approach seek to analyze the social behavior of human groups. So, for anthropologists, culture is the way of life of community, ways in which people perceive and organize their life and their business. Studies on the culture of these groups try to seek explanations of behavior patterns, so that, neglecting culture has serious implications for the development of peoples. Thus culture is the most powerful tool for research and determination of our identity.

Vargas [2007] stands out as a result of extensive studies on definitions of culture made by Kluckhohn [1962] came to the following conclusion: "Culture 
consists of patterns, explicit and implicit, of and for behavior acquired and transmitted by symbols constituting the distinctive achievement of human groups, including their incorporation into devices ... ". Thus, culture is the set of forms and ways in which a society responds to the challenges of their existence in their own geography and time.

Clifford Geertz [1983] tells us that "culture is the fabric of meaning in terms of which human beings interpret their existence and experience, also as they drive their actions." The study of symbols and meaning processes within anthropology began to be confined to fields such as religion, myth or magic, but generally remained the notion that the symbolic aspects of reality were secondary.

The culture is the way a human group has learned to live and transmit that lifestyle, to become social groups then develop their own language to express their culture, their personalities, their features, the face of a people of a community.

According to anthropologist Ralph Linton [1936], culture is a continuous process, which contains settings though, is constantly changing. The settings are the values and beliefs that tend to integrate and unify the culture.

To Terpastra and David [1985] [Vargas, 2007] define "people's culture is its distinctive patterns of behavior and manners underlying beliefs, values, norms and assumptions. Culture is learned and shared by members of a society and has an overwhelming influence on their behavior. therefore culture gives solutions to problems that all societies must solve if they are to remain viable. "this definition identifies the following elements:

1. Culture is learned, not born with it.

2. Culture is shared by members of a society.

3. Culture influences behavior.

4. Culture develops patterns where symbols and meanings are interrelated, and

5. Culture includes instrumental and expressive elements.

Furthermore, Leslie A. White [1975] [in Vargas, 2007] argues that "culture is the kind of things and events symbolize dependent, as are seen in an extrasomatic context." For White culture has elements attitudinal, ideological, sociological and technological changes that make it different from the behavior arguing that culture is not the act itself, but what this act symbolizes.

According to Kahn [1975], [cited Vargas, 2007] man invents and uses artifacts of culture in their daily lives, changes the forces of nature to some extent, alter the external world, creates instruments and tools, weapons, buildings, means of locomotion, transportation and communication, adapts to the world created through the development of technical skills of their culture, using his senses, his arms and legs to create secondary environments. 
In summary, anthropologists assert that all human groups, have their own culture which are points of identification and understanding with other groups in cognitive, behavioral and emotional.

Regarding the definition of communication, Asuncion-Lande [1983] ${ }^{2}$ takes several authors and adopted the following: "Communication is the process of transmitting messages and share meanings through symbols. Symbols can be linguistic, nonverbal, pictorial, or other annotations. Together or in combination, have or transmit messages. The processes of selection, organization and interpretation of symbols are included in the transmission of messages. "

The interpretation, feedback and the environment are issues to consider in this communication process because meanings change according to culture and individual experience, if not correct, the communication fails. The feedback helps to ensure the correct interpretation of the message. The communication channels can be face to face and interact sight, smell, hearing, touch and taste. You can also use other means such as telephone, computer, etc.

Asuncion-Lande mentions the social nature of human beings and make use of symbols to convey the same social knowledge that reflects the collective perception of reality therefore differs between cultures.

In international or multicultural contexts requires a better understanding and recognition of the impact of culture on communication behavior.

Several studies have been conducted to identify the critical factors that arise in the process of communication between people with different cultural backgrounds. Potentially problematic are: language, nonverbal codes, world outlook, which plays role in relationships and thinking patterns. [Samovar y Porter, 1976; Sitaram y Cogdell, 1976; Dodd, 1977; Asunción Lande, 1978; Sarbaugh, 1979; Argyle, 1982]. [Citados por Asunción-Lande, 1983].

Language is the most obvious factor in intercultural communication through it because people accumulate, share, give and receive information.

In the study of intercultural communication is widely believed that the meaning assigned to the word is partly the result of differences and cultural experiences. A seemingly straightforward translation of a familiar word will have a different connotation in a different language.

Therefore, intercultural communication is defined as a subset of communication with strangers of different national cultures [Gudykunts, 1980]. Nonverbal communication is equally important that the language as it is used to reinforce or contradict the verbal message or provide feedback from the receiver. Examples of nonverbal communication are body movements.

\footnotetext{
2 Asuncion-Lande is professor of communication at the University of Kansas. It written numerous articles on intercultural communication and development communicative, social and linguistic.
} 
Postures, gestures, facial expressions and eye movements, the physical distance between people.

\section{A living experience on intercultural communication.}

Ana, a teacher whose native language is English and French second language, was hired by a private university in the city of Culiacan, Sinaloa, Mexico. Result of this contract she changed her residence in this city. In an interview she was asked his opinion about the experience he had spent in the process of integration to the new work culture. She mentioned that it was not possible to separate the intercultural experience at work without talking about everyday life so that his thoughts were both her life and at work.

To inquire about what had been his biggest challenge living in this city she replied:

"Perhaps the biggest and most obvious challenge one faces in a foreign culture is that of communication. I am a native English speaker and French is my second language.

It seemed like on a daily basis, I was reminded of a line from a Steve Martin movie: "Those French...they have a word for *everything*!", except in my case I substituted "Mexicans" for "French." Apart from "buenos dias," the sheer lack of vocabulary made it very difficult to communicate even the most basic thoughts".

In the classroom, their activity was reduced often draw on the board I needed to communicate to their students.

In their groceries found her main challenge, mentioned:

"...I shopped by looking at the pictures on the product packages as I tried to stock my kitchen. I remember having a serious problem with ants in my rented house. I did manage to find the insecticide aisle in the store, but I didn't know what ants were called in Spanish. I chose a product with an illustration of an ant on the front and found a clerk. "Tengo beaucoup de these," I said to him in Spanish, French and English while pointing to the ant on the container. I simply wanted to know if this was the best product to get rid of the ants, but somehow it got lost in the "translation." I finally bought the product with the ant on the front and hoped for the best".

Similarly mentions that when people spoke to her in Spanish she immediately replied in French, says: “... a phenomenon I am sure a good linguistics professor could explain", although I had no idea what people were saying she automatically answered in French.

As her Spanish vocabulary grew, she presented another problem, the accent and pronunciation. It states:

"Without the normal visual cues when speaking face-to-face, it was most acute on the telephone. Calling for a pizza delivery: "Key-err-oh un peeetza medi-anna," I said to girl taking my order. "Qué?" I repeated what I had said, exactly. "Qué...qué?" was her reply. This went on for a minute or two, then finally the girl's frustration got the better of her: "Ana ya no trabaja aqui!" she told me, and hung up the phone." 


\section{Fabiola Ponce Durán}

In this regard notes that even with the correct pronunciation and vocabulary communication often did not work, consider the following:

"I had left my car at the mechanic's. He was preparing to move it so he could fix it, but there was a hydraulic jack behind one of the rear tires. I told him, "Cuidado con el gato," "gato" being the word here for jack. "Cúal gato?" he said. I pointed to the jack, proud that I at least knew the correct word. "Eso no es un gato," he said to me, "es un *jack."

These anecdotes now you are funny, but at the time they occurred a sense of frustration and helplessness felt by not being able to communicate with people who had contact with, having the feeling that the feeling was mutual.

Thus, things that seem simple in our own culture, like going to the store, talking on the phone, give and ask for directions to a place even order pizza, as the case of our interviewee, become virtually impossible without a good translator and a good dose of individual perseverance. Another anecdote that tells the respondent:

"Going to the doctor, for example, is very difficult when one does not know the body parts or the various ways of describing what hurts. I remember taking comfort in the fact that there was hope... at least the Spanish alphabet was nearly the same as the English one. "It could be worse," I thought, "You could be in Japan or China."

The customs are another critical aspect of cultural differences. Account of a friend of hers a Chilean who had gone to live in Quebec after the Pinochet coup, about the customs mentioned:

"...She found it very strange that in Quebec, in the winter, people carried their shoes everywhere in plastic bags. I explained to here that it was because of the snow. In winter, people wear boots in the snow. After arriving at someone's home or office, it was customary to remove the boots so as not to track snow inside, hence, the need to carry one's shoes in a bag.

Moreover, in her experience as a teacher tells a story that happened in the classroom.

"I remember being surprised in my classes when a student would ask permission to leave the room to blow his or her nose. At first, I thought it was just a ruse to get out of the classroom and do something else (drink water, talk to a friend, skip the class, etc.). I also remember being astounded when, after telling him or her no, the student would simply let his or her nose run before using a Kleenex in front of others."

She mentions that the biggest cultural differences and customs that were found living in Mexico was on the concept of time. In cultures of North America, "time is money", in Latin America, time is a different thing. Many studies have been done on this aspect and there are theories as to why the time means different things to different cultures. 
At the beginning of my adventure in Mexico, however, I found it very frustrating for someone to ask to meet at, say, $7 \mathrm{pm}$, only to finally show up a little after $8 \mathrm{pm}$. I have since discovered that what the Mexicans themselves say is true: if you want someone to arrive at $5 \mathrm{pm}$, tell them the meeting is at 4:30 pm."

In conclusion to her interview said that the deal with a different culture is a very frustrating if you do not have the necessary tools for communication, even the most mundane activities become complicated. A sense of isolation is presented to the inability to communicate and not be familiar with the customs which creates a depression in the adaptation process.

Finally concludes

"The good intentions of those in the host culture, a lot of individual perseverance, an open mind and a good dose of tolerance on all sides went a long way toward facilitating my personal adaptation to living and working in Mexico"

\section{Reflections}

The examples cited by Professor interviewed are, according to AsuncionLande, a pattern of thought by which the world is perceived reconcile with the empirical.

This is checked in intercultural communication when interacting with people from different cultures to communicate their skills are subjected to the test and have the ability to communicate in unfamiliar contexts or with strangers can mean the difference between prolonging the stay and enjoy interpersonal encounters, and they mean a continuous anxiety.

It was observed that the critical factors of intercultural communication in the case above are: language as more important, the meaning of the words also, customs and nonverbal language.

On the frustration and impotence, Asuncion-Lande notes that are manifestations of a culture shock, "the phenomenon of confusion or discomfort experienced upon being exposed to a sudden change" [pp.11]

All these aspects have correspondence with the theoretical perspective described above and leads us to consider to find tools to help improve the skills of the people who come from abroad and are or experience intercultural or multicultural situations. Not only will help people to better adapt to the environment in which to unfold but the institutions that hire foreign staff for an insert to work and pleasant culture.

Asuncion-Lande suggests some requirements to acquire those skills.

1. Be aware of your own culture, which will allow them to be more sensitive when interacting with other cultural identities but not necessarily have to agree to own subjective reality.

2. Avoid generalizations about other cultures. No stereotype and see the 


\section{Fabiola Ponce Durán}

differences between cultures and their complexities.

3. Accept the principle of cultural relativity. Each culture is unique and its premises are as valid as any other.

4. Adopt an open attitude towards the change to avoid the culture shock arises from: the experience derived from dealing with other people with different backgrounds. Due to lack of knowledge of other cultures. Limited experience in dealing with cultural differences. The personal rigidity

5. Be creative and experimental to reach intercultural have a skill that requires quick responses, constant adaptation and adjustment to the needs of spontaneous communication.

\section{Conclusion}

Today, acquiring intercultural skills becomes essential to meet the challenges presented by globalization. It is increasingly common in our environment coexist with people of different cultures, or, to be the ones we should leave our country and deal with the experience of living abroad. This not only affects individual people but affects the organization we work for the success of the relationship will be based on the ability to communicate with people from other cultures, languages and customs.

\section{References}

N Asunción-Lande (1986). La comunicación humana. México: Mc Graw Hill. - lie.upn. $\mathrm{mx}$.

García Oscar (2007). La cultura humana y su interpretación desde la perspectiva de la cultura organizacional. Pensamiento \& Gestión Universidad del Norte. No. 22.

Geertz, C. (1983) Local Knowledge. Further essays in interpretative anthropology. New York: Basic Books

Gudykunst, William B. (1980). Toward a 'Model' of Intercultural Relationship Development. Paperpresented at the annual convention of theSpeech Communication Association, New York, November, 1980

Samovar, Larry, and Richard Porter (eds.), Intercultural Communication: A Reader, Belmont, CA.: Wadsworth Publishing Company, 1972, 1976, 1982.

Vargas Hernández, J.G.: (2007) La culturocracia organizacional en México, Edición electrónica gratuita. Texto completo en www.eumed.net/libros/2007b/ 301 